\title{
Current status and management of coffee leaf rust in Brazil
}

\author{
Laércio Zambolim ${ }^{1}$
}

Received: 12 May 2015 / Accepted: 15 December 2015 / Published online: 25 January 2016

(C) Sociedade Brasileira de Fitopatologia 2016

\begin{abstract}
In Brazil, coffee leaf rust, a fungal disease caused by Hemileia vastatrix Berk. et Br., was first detected in Coffea arabica in January 1970, in the southern region of Bahia state. Today, the disease is present in virtually all arabica and conilon (Coffea canephora) coffee-growing areas of Brazil, and continues to threaten coffee production with losses that range from 30 to $50 \%$. The disease is usually less severe at elevations above $1,200 \mathrm{~m}$, where the environment is less conducive for the rust. Disease risk is increased in arabica coffee compared to conilon, and lower production is expected in the year following an epidemic due to early defoliation and drying of branches. Several varieties were developed in the country using sources of resistance from germplasm collections in Portugal. However, very few are completely resistant, instead exhibiting various levels of partial resistance. The disease is currently managed through the use of protectant and systemic fungicides including copper, triazoles and strobilurins that should be applied following rules of decision that vary according to the risk scenario. A review of the biology and epidemiology of coffee rust in Brazil is presented and the best management practices for controlling the disease based on advances in breeding for resistance and crop protection are discussed.
\end{abstract}

Keywords Coffea arabica $\cdot$ Coffea canephora $\cdot$ Hemileia vastatrix $\cdot$ Chemical control $\cdot$ Resistance

Section Editor: Emerson Del Ponte

Laércio Zambolim zambolim@ufv.br

1 Departamento de Fitopatologia, Universidade Federal de Viçosa, Viçosa, MG 36570-900, Brazil

\section{Introduction}

In Brazil, coffee leaf rust was first found in $C$. arabica in January 1970, in the southern region of Bahia state, and four months later the disease was found in almost all coffee plantations in the country (Chaves et al. 1970). Nowadays, the disease can be found in virtually all regions where arabica (Coffea arabica) and conilon (Coffea canephora) coffee are grown and is considered the main coffee disease of Brazil and worldwide (Rodrigues-Junior 1990; Avelino et al. 2015). Since 2012, there was a surge of coffee rust epidemics in Central and South America, particular in Nicaragua, Ecuador, El Salvador, Panama and Honduras, where losses were estimated in the range of 30 to $90 \%$ (Avelino et al. 2015).

Currently, in coffee-producing regions of Brazil that experience a warm weather, and where mostly susceptible conilon coffee is cultivated, the disease can reduce yields by 30 to $50 \%$ depending on the level of resistance of the genotype (Capucho et al. 2013a). The rate of yield reduction, however, varies among regions and years and is dependent on the level of epidemics in the previous year that affect coffee berry yield in the next year, especially for arabica coffee (Zambolim et al. 1992). The widely adapted but susceptible arabica coffee varieties are grown at high plant density and often have unbalanced nutrition, which favors the disease. The disease can be managed by integrating several measures but still chemical control is the most effective and should be used based on rational criteria. This review aims at providing a brief summary of the knowledge on the biological and epidemiological factors affecting coffee rust epidemics in Brazil, as well as discussing the current efforts and challenges for managing a disease of greatest concern to coffee production. 


\section{Pathogen biology and genetic variability}

The disease is caused by Hemileia vastatrix Berk. et Br., a basidiomycete fungus of the Pucciniaceae family, determined by Berkeley when examining dried Coffea arabica leaves originated from Sri Lanka in 1869. The features that are unique to Hemileia are the mode of penetration, sporulation from the stomata, and the reniform, dorsally echinulate and ventrally smooth urediniospores forming the sori or uredinia (Rijo and Rodrigues-Junior 1978). Urediniospores formed in the uredinia are dikaryotic $(n+n$ ') and teliospores are unicellular, globose or napiform, smooth, which may germinate in situ producing basidia and basidiospores.

More than 50 races of $H$. vastatrix have been identified in the Coffee Rust Research Centre in Oeiras, Portugal (Varzea and Marques 2005). In Brazil, 15 of those races have been identified in Coffea arabica $\mathrm{L}_{\text {.: }} \mathrm{I}_{(\mathrm{v} 2 \mathrm{v} 5)}, \mathrm{II}_{(\mathrm{v} 5)}, \mathrm{III}_{(\mathrm{v} 1 \mathrm{v} 5)}$, VII $(\mathrm{v} 3 \mathrm{v} 5)$, $X_{(v 1 v 4 v 5)}, X I_{(v 5 v 7)}, X V_{(v 4 v 5)}, X I_{(v 1 v 2 v 3 v 4 v 5)}, X V I I_{(v 1 v 2 v 5)}$, $\left.X_{(\mathrm{XII}} \mathrm{v} 5 \mathrm{v} 6\right), \mathrm{XXIII}_{(\mathrm{v} 1 \mathrm{v} 2 \mathrm{v} 4 \mathrm{v} 5)}, \mathrm{XXIV}_{(\mathrm{v} 2 \mathrm{v} 4 \mathrm{v} 5)}, \mathrm{XXV}_{(\mathrm{v} 2 \mathrm{v} 5 \mathrm{v} 6)}$, $\mathrm{XXXIII}_{(\mathrm{v} 5 \mathrm{v} 7 \text { or } v 5 \mathrm{v} 7 \mathrm{v} 9)}$ and $\mathrm{XXXVII}_{(\mathrm{v} 2 \mathrm{v} 5 \mathrm{v} 6 \mathrm{v} 7 \mathrm{v} 9)}$, with race $\mathrm{II}_{(\mathrm{v} 5)}$ being the most prevalent (Chaves and Pereira 1980; Cardoso et al. 1986, 1988; Zambolim et al. 2005a; Fazuoli et al. 2005; Cabral et al. 2009; Capucho et al. 2012). In Coffea canephora var. conilon three physiological races were identified: $\mathrm{I}_{(\mathrm{v} 2 \mathrm{v} 5)}$, $\mathrm{II}_{(\mathrm{v} 5)}$ and $\mathrm{III}_{(\mathrm{v} 1 \mathrm{v} 5)}$ (L. Zambolim, unpublished results).

The mechanisms that lead to the surge of new H. vastatrix races are not well understood. Because the sexual stage of the fungus has not been found, mutation is hypothesized as the main mechanism leading to variability in the pathogen population (Varzea and Marques 2005). Also, selection pressure exerted by dominant resistance genes may lead to virulent mutants in the population. Cytological evidence indicates the occurrence of karyogamy and meiosis in asexual spores. However, most researchers ignore the hypothesis of genetic recombination (Chinnappa and Sreenivasan 1965; Rajendren 1967). Genetic abnormalities in the urediniospores were first noted by Rajendren (1967), who described the occurrence of karyogamy and meiosis within these supposed asexual spores based on cytological evidence. The author called them "uredinioid teliospores", but, subsequently, this nuclear process was disputed and it has been ignored since, within the context of coffee rust research.

A recent study by Brazilian scientists involving cytometric imagery of DNA content revealed the presence of hidden sexual reproduction within asexual spores (urediniospores) of H. vastatrix (Carvalho et al. 2011). According to the authors, this type of reproduction, called cryptosexuality, may explain the frequent and rapid emergence of new physiological races of $H$. vastatrix. More recently Maia et al. (2013) reported no significant differences between the pathogen populations based on the genetic differentiation, although they were collected from different hosts. Their data showed that the evolution of $H$. vastatrix in coffee does not occur in a specialized way and can be explained by the successive crossings between the two species of coffee through the years.

\section{Symptoms, disease cycle and epidemiology}

The symptoms and general cycle of coffee rust are well known and have been described by several authors (Rayner 1961; Nutman and Roberts 1963; Montoya and Chaves 1974). Briefly, small patches of pale yellow color (1-3 mm of diameter) appear and expand (up to $20 \mathrm{~mm}$ of diameter) on the abaxial side of the leaves. Uredinia form in the chlorotic spots where powdery-like yellowish-orange urediniospores are produced. Chlorotic yellow spots appear on the adaxial side of the leaves, which becomes necrotic. Urediniospores produced in infected plants are the main primary inoculum for coffee rust epidemics. The urediniospores land, germinate and form an appresorium on the adaxial side of the leaves. A penetration peg is formed and the substomatal chamber is colonized by the intercellular mycelium and the haustoria. First symptoms of the disease appear as chlorotic spots. At the end of the latent period, uredinia are formed and yellowish-orange urediniospores are easily released to the surroundings, eventually escaping the canopy. The number of urediniospores produced in the uredinium is significantly affected by host resistance, especially in conilon coffee.

Eventually, telia and diploid teliospores (2n) are formed and germinate producing pro-mycelia (basidia) and basidiospores (n) on four sterigmata. Thus far, the role of basidiospores in the fungal life cycle remains unknown. Attempts to infect coffee and other plants with basidiospores have been unsuccessful. The pycnial and aecial stages of fungus are yet to be found in nature. Thus, the disease is considered an autoic and macrocyclic rust, where the uredia, telia and basidia stage occur in coffee plants.

With regards to epidemiology, urediniospores produced on disease plants may spread over long distances by wind, reaching $1,000 \mathrm{~m}$ up in the atmosphere and potentially reaching coffee plantations located thousands of miles away from the source (Martinez et al. 1975). Within the canopy, rainfall plays an important role in spreading the pathogen due to splashing of raindrops from one leaf to another (Chaves et al. 1970; Kushalappa and Chaves 1980). The optimum temperature range for germination of uredioniospores was estimated to be $21-25^{\circ} \mathrm{C}$ in the absence of light (Nutman and Roberts 1963; Rayner 1961; Montoya and Chaves 1974; Capucho et al. 2013a). Polynomial models were fitted to data describing the relationship between temperature and germination. The optimum temperature for maximum germination rate was estimated in $23{ }^{\circ} \mathrm{C}$ and the maximum and minimum temperature that prevented germination were estimated in 32.5 and $12.5{ }^{\circ} \mathrm{C}$, respectively (Kushalappa 1978; 
Kushalappa and Chaves 1980; Kushalappa et al. 1984). An exponential equation was fitted to data describing the relationship between leaf wetness duration and rust severity (Kushalappa et al. 1984). The duration of the latency period ranges from 20 to 55 days under field conditions, most commonly lasting 25 to 35 days (Moraes et al. 1976). Latency period is strongly influenced by temperature and is significantly extended when temperatures are higher than $28{ }^{\circ} \mathrm{C}$ or lower than $18{ }^{\circ} \mathrm{C}$ (Zambolim et al. 2005b). Early field observations showed that rust severity was strongly associated with diseased leaf area covered by urediniospores and with the duration of leaf wetness. Leaf area with urediniospores, rainfall and the combination of both parameters explained 73,69 and $90 \%$ of the variation of leaf rust severity, respectively (Kushalappa and Chaves 1980; Kushalappa et al. 1986). The foliar area with visible urediniospores and two weather-related variables (minimum temperature and rainfall) explained $91 \%$ of the variation in disease severity (Kushalappa 1978).

In regions where temperatures are lower than $16{ }^{\circ} \mathrm{C}$ or higher than $30{ }^{\circ} \mathrm{C}$, the disease may still be found but does not threaten the production. The severity of coffee rust epidemics has also been associated with field elevation above sea level (Bock 1962; Gree 1993). In Brazil, coffee plantations at sites above $1,200 \mathrm{~m}$ do not usually require fungicide sprays because rust incidence rarely reaches $20 \%$ at harvest. One explanation is that annual rainfall levels do not exceed 1,300 to $1,500 \mathrm{~mm}$. On the contrary, arabica coffee grown in Central America at elevations exceeding 1,500 m may suffer losses by rust due to a wetter (1,800-3,000 mm of rainfall annually) and warmer environment compared to Brazil.

The severity of coffee rust seems to be strongly associated with fruit berry load (Zambolim et al. 1992). During years of low berry production, the disease is usually not severe. However, greater care should be taken to protect coffee trees against rust during high yield years. In such cases, decisions of what and when to spray, and the interval between applications, need to take into account weather variables such as temperature, relative humidity, leaf wetness and rainfall.

In Brazil, the temporal progress of coffee rust in most coffee-growing regions during high yield years is as follows: disease onset occurs in December-January, increases exponentially during March-May, and peaks in June-July (depending on altitude). After harvest, the intensity of the disease declines due to cooler temperatures and leaf fall. In high yield years, rust incidence may reach $90 \%$ in susceptible varieties under favorable weather (Fig. 1). The rate of leaf defoliation at harvest depends on rust incidence level, natural leaf senescence and operation of manual or mechanical harvesting. In a year subsequent to an epidemic year, because production is low, rust incidence may not reach $25 \%$ even under favorable weather conditions.

The temporal progress of coffee leaf rust epidemics in conilon varieties is affected by the plant origin (clonal or seedderived), planting density, nutrition and weather conditions (Zambolim et al. 2015). The pruning of conilon clonal varieties differs from that of arabica varieties: clonal conilon plants are pruned after the fourth harvest to allow the growth of new branches at the base. Depending on the clone, conilon plants do not suffer severe premature defoliation much as arabica varieties do. Also, the number of pustules and number of urediniospores per pustule are both lower in conilon clones compared to arabica varieties. This might explain the high level of partial resistance of most conilon clones to leaf rust (Zambolim et al. 2015). However, in susceptible clones such as $12 \mathrm{~V}$ of the Vitoria clonal variety, rust can reach severe levels and cause premature defoliation that leads to significant yield losses. All of these variables influence the temporal dynamics of the disease on conilon varieties, for which the peak of rust severity may occur in July or in January in different years
Fig. 1 Disease progress curve of coffee leaf rust on Coffea arabica var. Catuai 144 and weather variables recorded during two seasons of low berry yield following a high berry and severe epidemic year

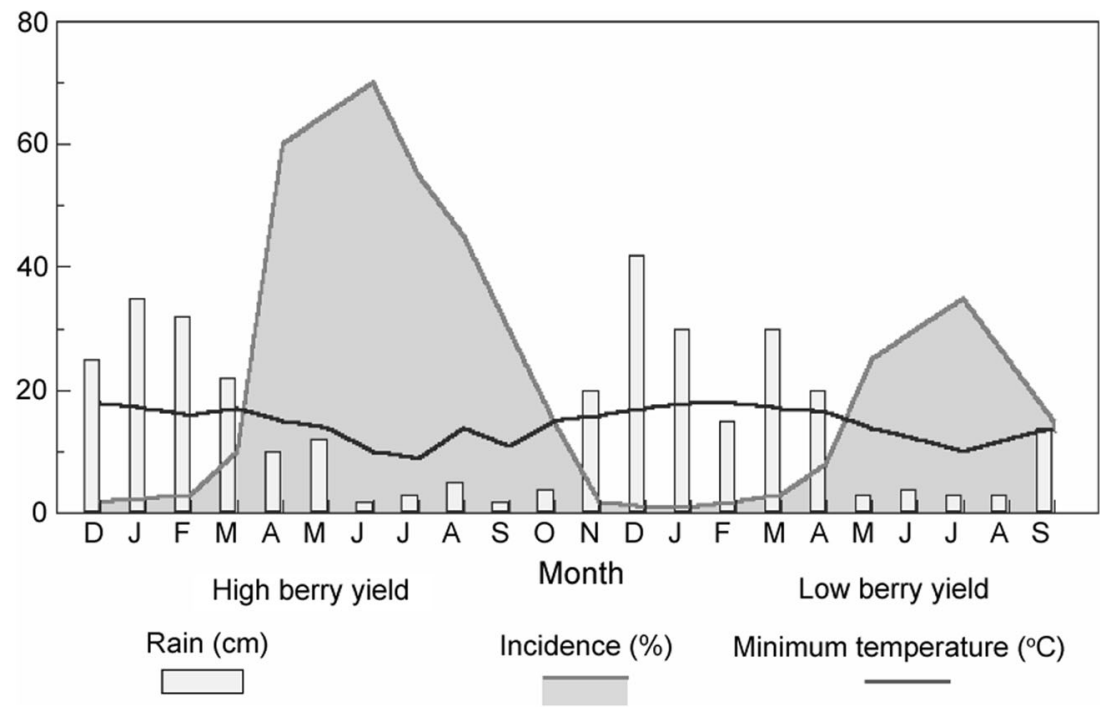



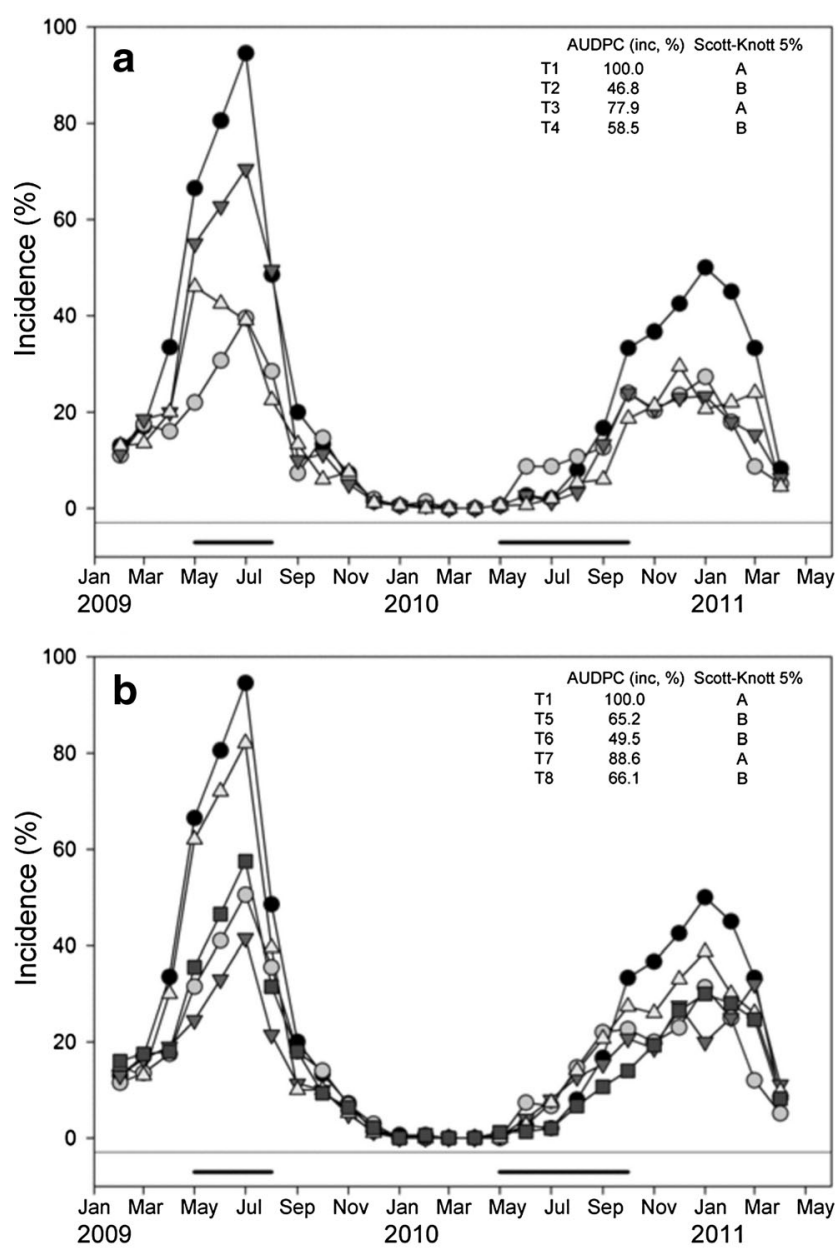

Fig. 2 Conilon coffee leaf rust progress curves under different fungicides and the check treatments. a. $-* \mathrm{~T} 1$ - Check; $-\infty-\mathrm{T} 2$ - Cyproconazole and thiamethoxam via soil; $\rightarrow-\mathrm{T} 3$ - Triadimenol and imidacloprid via soil; $\triangle-\mathrm{T} 4$ - Flutriafol and imidacloprid via soil. b. Treatments T1 and T5 to T8: - $-\mathrm{T} 1$ - Check; - $-\mathrm{T} 5$ - Cyproconazole and thiamethoxam via soil associated with cyproconazole via foliar spray; $\rightarrow-\mathrm{T} 6$ - Thiamethoxam and cyproconazole via soil associated with azoxystrobin and cyproconazole via foliar spray; $-\Delta-\mathrm{T} 7$ - Triadimenol and imidacloprid via soil associated to trifloxystrobin and cyproconazole via foliar spray; $\rightarrow$ T8 - Flutriafol and imidacloprid via soil associated with flutriafol via foliar spray. In both $\mathbf{a}$ and $\mathbf{b}$, the horizontal line (-) indicates the time of year when the climate is most favorable to the disease. Adapted from Capucho et al. (2013b)

(Fig. 2). For this reason it is recommended to monitor the disease before a decision to spray is made (Zambolim et al. 2015).

\section{Developments in breeding for rust resistance}

Resistant varieties are the most effective control measure for coffee leaf rust either in arabica or in conilon varieties, and has been explored by conventional breeding methods. Although there are known sources of monogenic, oligogenic, and polygenic resistance (Alvarado 2005; Bettencourt and Noronha-
Wagner 1971; Bettencourt and Rodrigues 1988; Fazuoli et al. 2005; Pereira et al. 2005; Silva et al. 2006), the genes that participate in the resistance mechanisms have not yet been identified at the molecular level. Coffee rust resistance is conferred, either independently or jointly, by genes $\mathrm{SH}$, $\mathrm{SH}$, SH3, SH4, SH5, SH6, SH7, SH8 and SH9, which may be supplanted in whole or in part by the virulence genes of the pathogen $v 1, v 2, v 3, v 4, v 5, v 6, v 7, v 8$ and $v 9$, respectively (Bettencourt and Rodrigues 1988). Genes SH1, SH2, SH4 and SH5 were identified in Coffea arabica (Bettencourt and Noronha-Wagner 1971), genes SH6 to SH9 were identified in, and introgressed from, Coffea canephora (RodriguesJunior et al. 1975; Bettencourt and Rodrigues 1988) and the gene SH3 from Coffea liberica (Prakash et al. 2004).

Several research groups in different regions of the world have attempted to obtain durable resistance to coffee rust. However, pathogen variability and the emergence of new races of the pathogen, as well as the occurrence of a complex of races, both illustrate the evolutionary potential of $H$. vastatrix populations and their consequent adaptation to the widespread deployment of resistance genes (Varzea and Marques 2005; Zambolim et al. 2005a; Cabral et al. 2009). The genetic variability of biotrophic fungi, including $H$. vastatrix, is usually high. More than 50 physiologic races of $H$. vastatrix have been identified from samples collected in different coffee-producing countries (Varzea and Marques 2005); 15 of these have been found in Brazil (Zambolim et al. 2005a). Among these, race II, which has the virulence gene $v 5$, predominates in commercial farming areas (Zambolim et al. 2005a). The majority of the commercial varieties planted in coffee-producing regions worldwide have the $\mathrm{SH} 5$ gene and are therefore susceptible to race $\mathrm{II}_{(\mathrm{v} 5)}$ of H. vastatrix (Fazuoli et al. 2005; Varzea and Marques 2005; Zambolim et al. 2005a). The main source of genes for resistance to all races of $H$. vastatrix is currently the Timor Hybrid, a genotype derived from a spontaneous crossing of $C$. arabica and C. canephora (Varzea and Marques 2005).

In the early 1970's, "Catimores" and "Sarchimores", rustresistant varieties from the Centro de Investigação das Ferrugens do Cafeeiro, Oeiras, Portugal, were introduced into Brazil and evaluated by researchers at the Universidade Federal de Viçosa (UFV) and other institutions. The resistant germplasm was crossed and backcrossed with the susceptible cultivars Catuaí and Mundo Novo over the next two decades and new varieties have been released. Several varieties, including more than 20 exhibiting levels of resistant have been developed by breeders at UFV-EPAMIG, Instituto Agronômico de Campinas (IAC) and Instituto Agronômico do Paraná (IAPAR), and have been made available to growers (Table 1).

Contrary to varieties that possess horizontal resistance, the use of varieties with vertical resistance is not a durable strategy due to the high physiological variability of the fungus. 
Table 1 Coffea arabica L. cultivars exhibiting highly susceptible (HS), susceptible (S) or complete resistance (R) reaction to leaf rust. Cultivars with quantitative (partial) resistance $(\mathrm{QR})$ also show plants varying from imune (I) to susceptible (S) reaction

\begin{tabular}{|c|c|c|}
\hline Reaction & Cultivar & Origin \\
\hline HS & Caturra & \\
\hline $\mathrm{S}$ & Mundo Novo & Natural crossing between Sumatra and red Bourbon \\
\hline S & Acaiá, Acaiá Cerrado & Selection of plants from the cultivar Mundo Novo \\
\hline $\mathrm{S}$ & $\begin{array}{l}\text { Catuaí Vermelho (Red Catuaí), } \\
\text { Catuaí Amarelo (Yellow Catuaí) }\end{array}$ & Crossing of yellow Caturra C476-11 with Mundo Novo CP 374-19 \\
\hline S & Ruby MG 1192 & Backcrossing of Red Catuaí (Caturra x Mundo Novo) with Mundo Novo \\
\hline S & Topázio MG 1190 & Crossing of Yellow Catuaí with Mundo Novo \\
\hline $\mathrm{QR} / \mathrm{I} / \mathrm{S}$ & Oeiras MG 6851 & $\begin{array}{l}\text { Developed by the pedigree method from the hybrid CIFC HW 26/5, resulting } \\
\text { from a crossing between red Caturra (CIFC 19/1) and Timor Hybrid } \\
\text { (CIFC 832/1) }\end{array}$ \\
\hline $\mathrm{R}$ & Sacramento MG 1 & $\begin{array}{l}\text { Derived from artificial hybridization between the cultivar Red Catuai IAC } 81 \\
\text { and the selection of Timor Hybrid UFV 438-52 }\end{array}$ \\
\hline $\mathrm{QR} / \mathrm{I} / \mathrm{S}$ & Pau-Brasil MG 1 & $\begin{array}{l}\text { Derived from artificial hybridization between the cultivar Red Catuaí IAC } 141 \\
\text { and the selection of Timor Hybrid UFV 442-34 }\end{array}$ \\
\hline $\mathrm{QR} / \mathrm{I} / \mathrm{S}$ & Paraíso MG H419-1 & $\begin{array}{l}\text { Derived from artificial crossing of the cultivar Yellow Catuaí IAC } 30 \text { and the } \\
\text { selection of Timor Hybrid UFV 445-46 }\end{array}$ \\
\hline $\mathrm{R}$ & Catiguá MG 1, MG 2 and MG 3 & $\begin{array}{l}\text { Derived from artificial crossing of the cultivar Yellow Catuaí IAC } 86 \text { and the } \\
\text { selection of Timor Hybrid UFV } 440-10\end{array}$ \\
\hline $\mathrm{QR} / \mathrm{I} / \mathrm{S}$ & Araponga MG 1 & $\begin{array}{l}\text { Derived from artificial hybridization between the cultivar Yellow Catuaí IAC } \\
86 \text { and the selection of Timor Hybrid UFV 446-08 }\end{array}$ \\
\hline $\mathrm{QR} / \mathrm{I} / \mathrm{S}$ & $\begin{array}{l}\text { Catucaí lineages 20/15-479; 2SL; } \\
\quad 785 / 15\end{array}$ & Crossing of Icatu with Catuaí \\
\hline \multirow[t]{2}{*}{$\mathrm{QR} / \mathrm{I} / \mathrm{S}$} & Obatã IAC 1669-20 & Originated from the hybrid CIFC H $361-4$ Villa Sarchi X Timor Hybrid 832/2 \\
\hline & I Tupi IAC 1669-33 & Originated from the hybrid CIFC H 361-4 Villa Sarchi X Timor Hybrid 832/2 \\
\hline $\mathrm{R}$ & Iapar 59 & $\begin{array}{l}\text { Originate from the hybrid CIFC H361-4, resulting from crossing of Villa Sarch } \\
\text { with Timor Hybrid }\end{array}$ \\
\hline $\mathrm{QR} / \mathrm{I} / \mathrm{S}$ & Acauã & Crossing of Sarchimor 1668 with Mundo Novo IAC 388-17 \\
\hline $\mathrm{QR} / \mathrm{I} / \mathrm{S}$ & IBC - Palma I, IBC- Palma II & Crossing of Catimor UFV 353 with Red Catuaí IAC 81 \\
\hline $\mathrm{QR} / \mathrm{I} / \mathrm{S}$ & Sabiá tardio & Crossing of Catimor 386 with Acaiá \\
\hline $\mathrm{QR} / \mathrm{I} / \mathrm{S}$ & Siriema & $\begin{array}{l}\text { Crossing of Coffea racemosa with Blue Mountain backcrossed with Catimor } \\
\text { UFV } 417\end{array}$ \\
\hline $\mathrm{QR} / \mathrm{I} / \mathrm{S}$ & Icatu vermelho, Icatu amarelo & $\begin{array}{l}\text { Interspecific hybridization between } C \text {. canephora cv. Robusta and red Bourbon } \\
\text { of } C \text {. arabica) }\end{array}$ \\
\hline
\end{tabular}

According to Maia et al. (2013), H. vastatrix populations in Brazil are not structured by host. The high genotypic diversity associated with the high gene flow in the $H$. vastatrix population is important information to be considered in breeding programs aimed at developing coffee cultivars with rust resistance. Cabral et al. (2015) reported great genetic diversity of Hemileia vastatrix populations on Coffea spp. Thus, breeding programs need to develop varieties with durable resistance for a highly fit and variable pathogen.

With regards to C. canephora var. conilon, seed-grown varieties possess poligenes for rust resistance (quantitative resistance), and there are from 9 to 15 clonal varieties exhibiting both qualitative and quantitative resistance to $H$. vastatrix. Examples of seed-grown varieties with quantitative resistance include Robusta Tropical and Robustão Capixaba. Examples of clones with qualitative resistance include $143,153,5 \mathrm{~V}, \mathrm{NV}$ and $\mathrm{A} 1$, and with quantitative resistance, $12 \mathrm{~V}, 8 \mathrm{~V}, 4 \mathrm{~V}$ and 03 .

\section{Chemical-based control strategies}

Widely used in Brazil and other South American countries, chemical control is based on the spray of protectant and/or systemic fungicides on the foliage (Zambolim et al. 2005b; SilvaAcuña et al. 1993a, b) (Fig. 3). Among protectant fungicides, copper-based ones such as Bordeaux mixture, copper oxychloride, copper oxides and hydroxides are the most effective (Zambolim et al. 2005b). Among systemic fungicides, triazoles are applied alone or in mixtures with QoI (strobilurin) fungicides, and are applied either on the leaves or in the soil (in this case, together with systemic insecticides for control of leaf 
Fig. 3 Decision diagram for the integrated management of coffee leaf rust in Coffea arabica and C. canephora in Brazil

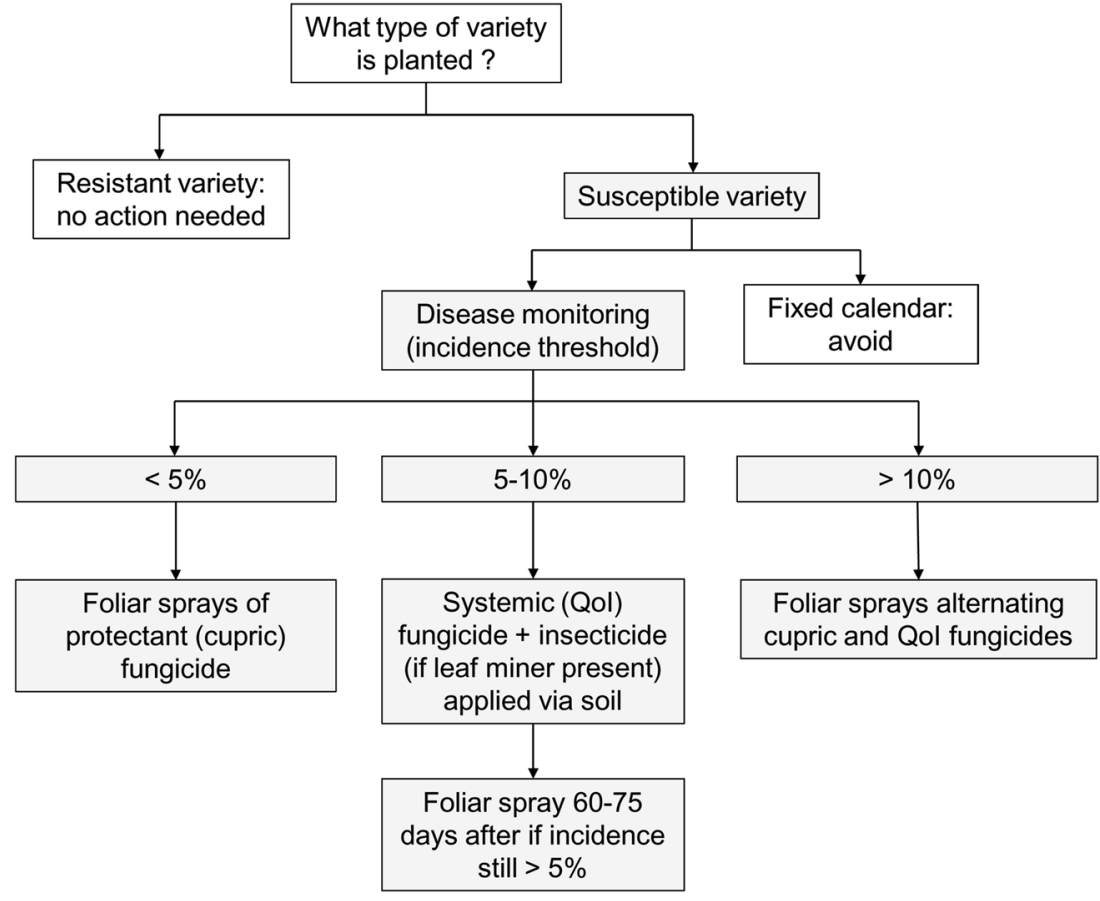

miner). The combined use of copper-based fungicides with systemic fungicides has the additional advantage of providing copper to the plants, besides reducing the risk of selecting fungicideresistant rust populations (Souza et al. 2011).

Various rules can be used to aid the decision of when to start fungicide applications. These include calendar-, weather-, phenology- and disease monitoring-based criteria. In years of high load of fruit berries, four to five sprays of protectant fungicides are usually performed from December to March/April at 30-day intervals, or two sprays of systemic fungicides (including a QoI), the first in January and the second in March. In any case, disease incidence and weather should be taken into account in the decision making process. In years of low load of fruit berries, the number of applications is reduced by half. The use of systemic fungicides combined with insecticide application via soil should be performed in the beginning of the rainy season (November in Brazil). The fungicide-plus-insecticide formulation should be applied in the soil around and beneath the branches of the plants. These applications should be made whenever there is sufficient moisture in soil, so that the active ingredients can be more effectively released and absorbed by the plant roots. In coffee-producing regions where leaf miner does not cause damage, the systemic fungicide can be applied to the soil alone (without the insecticide).

When spraying decisions are based on disease monitoring, 10 leaves are randomly collected per plant, totaling 100 leaves per plot, which are taken from the lower third of the plants and the middle of the branches (third or fourth pair of leaves). If rust incidence (percentage of symptomatic leaves) reaches $5 \%$, a systemic mixture including a QoI fungicide is highly recommended, otherwise cupric fungicides should be sprayed. One of the advantages of systemic over protectant fungicides is their ability to act curatively (after the infection is established). However, their curative efficacy is greatly reduced if rust incidence is greater than $10 \%$ in years of high fruit load (Souza et al. 2011). In this case, systemic fungicides should be used alternated with cupric fungicides to avoid the selection of fungicide-resistant strains.

Triazol fungicides applied alone or in combination with insecticide to the soil are efficient to control the disease in conilon coffee (Capucho et al. 2013b; Zambolim et al. 2015). The option to spray a triazol + strobilurin fungicide alone instead of applying triazol to the soil with insecticides (usually after the first rains in the beginning of the season) should be based on the disease incidence (5\% threshold) (Belan et al. 2014).

Rust on arabica or conilon coffee may also be controlled using a mixture of nutrients which exhibit fungicidal effect, such as the Viçosa mixture, a colloidal suspension of partially neutralized salts with calcium hydroxide ( $750 \mathrm{~g}$ copper sulfate pentahydrate, $300 \mathrm{~g}$ zinc sulfate, $400 \mathrm{~g}$ magnesium sulfate, $100 \mathrm{~g}$ boric acid, $400 \mathrm{~g}$ potassium chloride, 350-550 g calcium hydroxide, $\mathrm{pH}$ 5.6-5.8) and prepared at the time of application (Zambolim et al. 2005b, 2015). Advantages of this mixture are the control of other diseases such as brown eye 
leaf spot and the supply of mineral elements to the plants such as copper, zinc and boron. Results obtained at UFV since 1985 have shown a $80 \%$ yield increased compared to untreated plants (L. Zambolim, unpublished results). Viçosa mixture should be applied four to five times, starting in November or December and ending in March or April at a 30-day interval.

\section{Alternative control methods}

Several researchers have investigated alternative control methods such as biological control, use of plant extracts, mineral nutrition, silicates and induced host resistance (Costa et al. 2007; Santos 2007; Tratch and Bettiol 1997; Pereira 2008; Haddad et al. 2009; Carré-Missio et al. 2009; Carvalho et al. 2012; Carré-Missio et al. 2012; Lopes et al. 2013). In general, mineral nutrition and plant extracts show limited effects on coffee leaf rust (Santos 2007; Pereira 2008), contrary to biocontrol using Bacillus thuringiensis and B. subtilis that exhibited some effect (Bettiol et al. 1994; Cristancho 1995; Haddad et al. 2009). In one study, acibenzolar-S-methyl, Bacillus subtilis and Pseudomonas putida reduced fungal infection by $70 \%$ (Costa et al. 2007). Few attempts have been made to find a biological control agent acting as a hyperparasite of the urediniospores. In shaded and wet coffee plantations, white color signs of the fungus Lecanicillium lecani may be noticed colonizing pustules of Hemileia vastatrix (Chaves et al. 1970). Several species of Lecanicillium besides Lecanicillium lecani may be involved in such parasitism and deserve investigation. As to the use of calcium and potassium silicates, results showed that application was not efficient either as foliar spray or to the soil (Carré-Missio et al. 2009, 2012; Lopes et al. 2013). On the other hand, treatment with Viçosa mixture and Bordeaux mixture have reduced rust incidence by $75 \%$ due to the effect of copper sulfate (Souza et al. 2011; Carvalho et al. 2012).

\section{Concluding remarks}

Regardless of the advances in research during 45 years after the introduction of coffee leaf rust in Brazil, the disease still poses a significant threat and increases production costs in coffee production in the country. This scenario is due to the combination of favorable environmental conditions in most coffee-growing regions and the wide use of susceptible varieties, for which fungicides that are of relatively low cost and toxicity are applied. Research efforts should keep focusing on the development of varieties with durable resistance, discovery of new chemical molecules that can move systemically in the phloem and continuous monitoring of $H$. vastatrix populations.

\section{References}

Alvarado GA (2005) Evolution of Hemileia vastatrix virulence in Colombia. In: Zambolim L, Maciel-Zambolim E, Várzea VMP (eds) Durable resistance to coffee leaf rust. UFV, Viçosa, pp 99-115

Avelino J, Cristancho M, Georgiou S, Imbach P, Aguilar L, Bornemann G, Läderach P, Anzueto F, Hruska AJ, Morales C (2015) The coffee rust crises in Colombia and central America (2008-2013): impacts, plausible causes and proposed solutions. Food Sec 7:303-321

Belan LL, Jesus-Junior WC, Souza AF, Zambolim L, Tomaz MA, Alves FR, Ferrão MAG, Amaral JFT (2014) Monitoring of leaf rust in Conilon coffee clones to improve fungicide use. Austral Plant Pathol 44:5-12

Bettencourt AJ, Noronha-Wagner M (1971) Genetic factors conditioning resistance of Coffea arabica L. to Hemileia vastatrix Berk. \& Br. Agron Lusit 31:285-292

Bettencourt AJ, Rodrigues CJ (1988) Principles and practice of coffee breeding for resistance to rust and other diseases. Agronomy 4:199 234

Bettiol W, Saito ML, Brandão MSB (1994) Controle da ferrugem do cafeeiro com produtos a base de Bacillus subtilis. Summa Phytopathol 20:119-122

Bock KR (1962) Seasonal periodicity of coffee leaf rust and factors affecting the severity of outbreaks in Kenya Colony. Trans British Mycol Soc 45:289-300

Cabral PGC, Maciel-Zambolim E, Zambolim L, Lelis TP, Capucho AS, Caixeta ET (2009) Identification of a new race of Hemileia vastatrix in Brazil. Austral Plant Dis Notes 4:129-130

Cabral PGC, Maciel-Zambolim EM, Oliveira SAS, Caixeta ET, Zambolim L (2015) Genetic diversity and structure of Hemileia vastatrix populations on Coffea spp. Plant Pathol. doi:10.1111/ppa. 12411

Capucho AS, Maciel-Zambolim E, Freitas RL, Haddad F, Caixeta ET, Zambolim L (2012) Identification of race XXXIII of Hemileia vastatrix on Coffea arabica Catimor derivatives in Brazil. Austral Plant Dis Notes 7:189-191

Capucho AS, Zambolim L, Cabral PGC, Maciel-Zambolim E, Caixeta ET (2013a) Climate favorability to leaf rust in Conilon coffee. Austral Plant Pathol 24:511-514

Capucho AS, Zambolim L, Milagres N (2013b) Chemical control of coffee leaf rust in Coffea canephora cv. Conilon. Australas Plant Pathol 42:667-673

Cardoso RML, Zambolim L, Chaves GM (1986) Novas raças de Hemileia vastatrix Berk. et Br. identificadas em cafeeiros de genótipos complexos. Fitopatol Bras 11:318

Cardoso RML, Zambolim L, Chaves GM (1988) Ocorrência no Brasil da raça XVI de Hemileia vastatrix Berk. et Br. coletada de germoplasma de Coffea arabica no Estado de Minas Gerais. Fitopatol Bras 5:393-394

Carré-Missio V, Rodrigues FA, Schurt DA, Pereira SC, Oliveira MGA, Zambolim L (2009) Ineficiência do silício no controle da ferrugem do cafeeiro em solução nutritiva. Tropical Plant Pathol 34:416-421

Carré-Missio V, Rodrigues FA, Schurt DA, Moreira WR, Rezende DC, Korndorfer GH, Zambolim L (2012) Proteção local, não sistêmica, do silicato de potássio reduz os sintomas da ferrugem do cafeeiro. Tropical Plant Pathol 37:275-280

Carvalho CR, Fernandes RC, Carvalho GMA, Barreto RW, Evans HC (2011) Cryptosexuality and the genetic diversity paradox in coffee rust (Hemileia vastatrix). PLoS One 6, e26387

Carvalho VL, Cunha RL, Silva NRN (2012) Alternativas de controle de doenças do cafeeiro. Coffee Sci 7:42-49

Chaves GM, Pereira AA (1980) Presença de nova raça de Hemileia vastatrix em Minas Gerais. Fitopatol Bras 5:393-394

Chaves MG, da Cruz Filho J, Carvalho MG, Matsuoka K, Coelho DT, Shimoy CA (1970) Ferrugem do cafeeiro (Hemileia vastatrix Berk. 
\& Br). Revisão de literatura com observações e comentários sobre a enfermidade no Brasil. Seiva 30:1-75

Chinnappa CC, Sreenivasan MS (1965) Cytological studies on germinating teliospores of Hemileia vastatrix. Caryologia 18:625-631

Costa MJN, Zambolim L, Rodrigues FR (2007) Avaliação de produtos alternativos no controle da ferrugem do cafeeiro. Fitopatol Bras 32: $147-152$

Cristancho AMA (1995) Effecto protector de la bactéria Bacillus thuringiensis em plants de café contra el desarrollo de Hemileia vastatrix. Cenicafé 46:140-151

Fazuoli LC, Oliveira ACB, Toma-Braguini M, Silvarolla MB (2005) Identification and use of sources of durable resistance to coffee leaf rust at the IAC. In: Zambolim L, Maciel-Zambolim E, Várzea VMP (eds) Durable resistance to coffee leaf rust. UFV, Viçosa, pp 137-185

Gree G (1993) Epidemiology of coffee leaf rust in the Eastern Highlands. Newsletter Coffee Res Inst 2:16-20

Haddad F, Maffia LA, Mizubuti ESG, Teixeira H (2009) Biological control of coffee leaf rust by antagonistic bacteria under field conditions in Brazil. Biol Control 49:114-119

Kushalappa AC (1978) Análise quantitativa e qualitativa da intensidade de ferrugem do cafeeiro (Hemileia vastatrix Berk. \& Br.), durante a estação chuvosa, em Viçosa, MG. Fitopatol Bras 3:118

Kushalappa AC, Chaves GM (1980) An analysis of the development of coffee rust in the field. Fitopatol Bras 5:95-183

Kushalappa AC, Akutsu M, Oseguera SH, Chaves GM, Melles CA, Miranda JM (1984) Equations for predicting the rate of coffee rust development based on net survival ratio for macrocyclic process of Hemileia vastatrix. Fitopatol Bras 9:255-271

Kushalappa AC, Hernández TA, Lemos HG (1986) Evaluation of simple and complex coffee rust forecasts to time fungicide application. Fitopatol Bras 11:515-526

Lopes UP, Zambolim L, Souza Neto PN, Souza AF, Capucho AS, Rodrigues FA (2013) Effect of foliar application of potassium silicate on the progress of coffee leaf rust. Tropical Plant Pathol 38: $547-551$

Maia TA, Maciel-Zambolim E, Caixeta ET, Mizubuti ESG, Zambolim L (2013) The population structure of Hemileia vastatrix in Brazil inferred from AFLP. Austral Plant Pathol 42:533-542

Martinez JÁ, Palazzo DA, Karazawa M, Monteiro MVM, Reu NR (1975) Presença de esporos de Hemileia vastatrix Berk. \& Br., agente causal da ferrugem do cafeeiro, em diferentes altitudes, nas principais áreas, cafeeiras dos Estados de São Paulo e Paraná (Brasil). Biológico 41:77-88

Montoya RH, Chaves GM (1974) Influência da temperatura e da luz na germinação, infectividade e período de geração de Hemileia vastatrix Berk. \& Br. Experientiae 18:239-266

Moraes AS, Sugimori MH, Ribeiro IJA, Ortolani AA, Pedro JR MS (1976) Período de incubação de Hemileia vastatrix Berk. \& Br. em três regiões do Estado de São Paulo. Summa Phytopathol 2: $32-38$

Nutman FJ, Roberts FM (1963) Studies on the biology of Hemileia vastatrix Berk. \& Br. Trans British Mycological Soc 46:27-48

Pereira RB (2008) Extrato de casca de café, óleo essencial de tomilho e acibenzolar-S-metyl no manejo da cercosporiose-do-cafeeiro. Pesq Agropec Bras 43:1287-1296

Pereira AA, Sakiyama NS, Zambolim L, Moura WM, Maciel-Zambolim E, Caixeta ET (2005) Identification and use of sources of durable resistance to coffee leaf rust in the UFV/EPAMIG breeding program. In: Zambolim L, Maciel-Zambolim E, Várzea VMP (eds) Durable resistance to coffee leaf rust. UFV, Viçosa, pp 215-232

Prakash NS, Marques DV, Varzea VMP, Silva MC, Combes MC, Lashermes P (2004) Introgression molecular analysis of a leaf rust resistance gene from Coffea liberica into Coffea arabica L. Theor Appl Genet 109:1311-1317

Rajendren RB (1967) New type of nuclear life cycle in Hemileia vastatrix. Nature 213:105-106

Rayner RW (1961) Germination and penetration studies on coffee rust (Hemileia vastatrix Berk. \& Br.). Ann Appl Biol 49:493-505

Rijo L, Rodrigues-Junior CJ (1978) Processo de infecção da Hemileia vastatrix Berk. \& Br. em cultivares susceptíveis e resistentes de Coffea arabica L. Estudos Agronómicos 5:23-24

Rodrigues-Junior CJ (1990) Coffee rust: history, taxonomy, morphology, distribution and host resistence. Fitopatol Bras 15:5-9

Rodrigues-Junior CJ, Bettencourt AJ, Rijo L (1975) Races of the pathogen and resistance to coffee rust. Annu Rev Phytopathol 13:49-70

Santos FS (2007) Efeito de extratos vegetais no progresso de doenças foliares do cafeeiro orgânico. Fitopatol Bras 32:11-16

Silva MC, Várzea MPV, Guerra-Guimarães L, Azinheira HG, Fernandes D, Petitot AS, Bertrand B, Lashermes P, Nicole M (2006) Coffee resistance to the main diseases: leaf rust and coffee berry disease. Braz J Plant Physiol 18:119-147

Silva-Acuña R, Gonzalez-Molina EC, Zambolim L (1993a) Controle da ferrugem do cafeeiro com triadimenol via solo, na Venezuela. Fitopatol Bras 18:70-75

Silva-Acuña R, Gonzalez-Molina EC, Zambolim L (1993b) Controle da ferrugem em cafeeiros sombreados com formulações de triadimenol combinadas com oxicloreto de cobre na Venezuela. Summa Phytopathol 19:189-194

Souza AF, Zambolim L, Cecon PR (2011) Chemical approaches to manage coffee leaf rust in drip irrigated trees. Austral Plant Pathol 40: 293-300

Tratch R, Bettiol W (1997) Efeito de biofertilizantes sobre o crescimento micelial e a germinação de esporos de alguns fungos fitopatogênicos. Pesq Agropec Bras 32:1131-1139

Varzea VMP, Marques DV (2005) Population variability of Hemileia vastatrix vs coffee durable resistance. In: Zambolim L, MacielZambolim E, Várzea VMP (eds) Durable resistance to coffee leaf rust. UFV, Viçosa, pp 53-74

Zambolim L, Silva-Acuña R, Vale FXR, Chaves GM (1992) Influencia da produção do cafeeiro sobre o desenvolvimento da ferrugem (Hemileia vastatrix). Fitopatol Bras 17:32-35

Zambolim L, Maciel-Zambolim E, Vale FXR, Pereira AA, Sakyiama NS, Caixeta ET (2005a) Physiological races of Hemileia vastatrix in Brazil: physiological variability, current situation and future prospects. In: Zambolim L, Maciel-Zambolim E, Várzea VMP (eds) Durable resistance to coffee leaf rust. UFV, Viçosa, pp 53-74

Zambolim L, Vale FXR, Maciel-Zambolim E (2005b) Doenças do cafeeiro (Coffea arabica e C. canephora). In: Kimati H, Amorim L, Bergamim-Filho A, Camargo LEA, Rezende JAM (eds) Manual de fitopatologia: doenças das plantas cultivadas, 4th edn. Ceres, São Paulo, pp 165-180

Zambolim L, Capucho AS, Silva MB (2015) Ferrugem do cafeeiro Conilon (Coffea canephora). In: Partelli FL, Giles JAD, Silva MB (eds) Café Conilon: manejo de pragas e sustentabilidade. CAUFES, Alegre, pp 167-186 